\title{
Clinical significance of platelet-derived growth factor receptor- $\beta$ gene expression in stage II/III gastric cancer with $S-1$ adjuvant chemotherapy
}

\author{
AKIO HIGUCHI $^{1}$, TAKASHI OSHIMA ${ }^{1}$, KAZUE YOSHIHARA ${ }^{1}$, KENTARO SAKAMAKI ${ }^{2}$, \\ TORU AOYAMA ${ }^{1}$, NOBUYASU SUGANUMA ${ }^{1}$, NAOTO YAMAMOTO ${ }^{1}$, TSUTOMU SATO ${ }^{1}$,

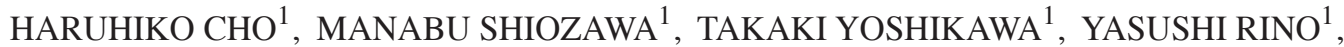 \\ CHIKARA KUNISAKI ${ }^{3}$, TOSHIO IMADA ${ }^{4}$ and MUNETAKA MASUDA ${ }^{1}$
}

\footnotetext{
${ }^{1}$ Department of Surgery, Yokohama City University, Yokohama, Kanagawa 236-0004; ${ }^{2}$ Clinical Research Coordinating Center;

${ }^{3}$ Gastroenterological Center, Yokohama City University Medical Center, Yokohama, Kanagawa 232-0024;

${ }^{4}$ Department of Surgery, Saiseikai Yokohamashi Nanbu Hospital, Yokohama, Kanagawa 234-8503, Japan
}

Received April 15, 2015; Accepted July 15, 2016

DOI: $10.3892 / 01.2016 .5494$

\begin{abstract}
Overall survival remains unsatisfactory in stage II/III gastric cancer, even after curative surgery and adjuvant chemotherapy. Platelet-derived growth factor receptor- $\beta$ (PDGFR- $\beta$ ) is associated with the proliferation of cancer cells. The present study therefore investigated the association of PDGFR- $\beta$ gene expression with patient outcome in 134 stage II/III gastric cancer patients who received adjuvant chemotherapy with $\mathrm{S}-1$. Relative PDGFR- $\beta$ gene expression was measured in surgical cancer tissue and adjacent normal mucosa specimens by reverse transcription-quantitative polymerase chain reaction. The PDGFR- $\beta$ gene expression levels were found to be significantly higher in the cancer tissues compared with the adjacent normal mucosa. A high level of PDGFR- $\beta$ gene expression was associated with a significantly poorer 5-year overall survival rate compared with a low level of $P D G F R-\beta$ expression. Upon multivariate analysis, $P D G F R-\beta$ gene expression was found to be an independent predictor of survival. Overall, the study indicates that PDGFR- $\beta$ overexpression in gastric cancer tissues is a useful independent predictor of outcome in patients with stage II/III gastric cancer who receive adjuvant chemotherapy with S-1.
\end{abstract}

\section{Introduction}

Gastric cancer is the fourth most common cancer globally and the second leading cause of cancer-associated mortality (1).

Correspondence to: Dr Takashi Oshima, Department of Surgery, Yokohama City University, 3-9 Fukuura, Kanazawa, Yokohama, Kanagawa 236-0004, Japan

E-mail: ohshimatakashi@yahoo.co.jp

Key words: PDGFR- $\beta$, tyrosine kinase receptor, stage II/III gastric cancer, adjuvant chemotherapy with $\mathrm{S}-1$, prognostic factor
Gastrectomy with D2 dissection and progress in chemotherapy have significantly improved survival times in patients with gastric cancer $(2,3)$. The standard treatment for stage II/III gastric cancer is curative resection and adjuvant chemotherapy. On the basis of the results of the Adjuvant Chemotherapy Trial of S-1 for Gastric Cancer, patients with stage II/III gastric cancer in Japan usually receive S-1 for 1 year after gastrectomy. However, despite treatment with $\mathrm{S}-1$, the 5-year overall survival rate is $71.7 \%$ and thus remains unsatisfactory (4). Therefore, great hope has been placed on the development of personalized medicine using biomarkers to improve outcomes in stage II/III gastric cancer.

Platelet-derived growth factor receptor- $\beta(P D G F R-\beta)$ is a cell surface tyrosine kinase receptor for members of the $P D G F$ family. $P D G F R-\beta$ is expressed in numerous types of human neoplasms, including gastric cancer (5-7). PDGFR- $\beta$ signaling has been reported to increase tumor cell proliferation in an autocrine manner (8), and to stimulate angiogenesis (9), recruit pericytes $(8,10)$ and regulate interstitial fluid pressure (IFP) in the stroma; PDGFR- $\beta$ thereby affects the transvascular transport of chemotherapeutic agents in a paracrine manner (11).

The present study was designed to evaluate the clinical significance of PDGFR- $\beta$ gene expression in patients with stage II/III gastric cancer who received curative resection followed by adjuvant chemotherapy with S-1.

\section{Materials and methods}

Patients and samples. The present study focused on surgically resected specimens of cancer tissue and adjacent normal mucosa obtained from 134 patients with stage II/III gastric cancer who underwent curative surgery without receiving pre-operative chemotherapy or radiotherapy. Tumor stage was evaluated according to the 7th edition of the International Union Against Cancer (UICC)-TNM classification of malignant tumors (12). The patients post-operatively received adjuvant chemotherapy with S-1. All patients were treated in the Department of Surgery, Yokohama City University (Yokohama, 
Kanagawa, Japan), the Gastroenterological Center, Yokohama City Medical Center (Yokohama, Kanagawa, Japan) or the Department of Gastrointestinal Surgery, Kanagawa Cancer Center (Yokohama, Kanagawa, Japan) between March 2002 and July 2010. Informed consent was obtained from all patients, and the study protocol was approved by the Ethics Committees of Yokohama City University Medical Center, Yokohama City University and Kanagawa Cancer Center. All tissue samples were embedded in optimal cutting temperature compound (Sakura Finetechnical Co., Ltd., Tokyo, Japan) and immediately stored at $-80^{\circ} \mathrm{C}$ until use. No patient had any other malignancies. The tissue specimens were stained with hematoxylin and eosin, and examined histopathologically. Sections that consisted of $>80 \%$ carcinoma cells were used to prepare total RNA.

RNA extraction and complementary DNA (cDNA) synthesis. Total RNA isolated from gastric cancer tissues and adjacent normal mucosa was prepared using TRIzol (Gibco; Thermo Fisher Scientific, Inc., Waltham, MA, USA). cDNA was synthesized from $0.4 \mu \mathrm{g}$ total RNA using an iScript cDNA synthesis kit (Bio-Rad Laboratories, Inc., Hercules, CA, USA), according to the manufacturer's instructions. Following synthesis, the cDNA was diluted to $0.2 \mu \mathrm{g} / \mu \mathrm{l}$ with water and stored at $-20^{\circ} \mathrm{C}$ until use.

Oligonucleotide primers for PDGFR- $\beta$ cDNA amplification by reverse-transcription polymerase chain reaction (RT-PCR). The oligonucleotide primers for $P D G F R-\beta$ were as follows: Sense, 5'-CGTGGCTTTTCTGGTATCTTTGAG-3' and antisense, 5'-CGTTGATGGATGACACCTGGAG-3'. $\beta$-actin was used as the internal control. The oligonucleotide primers for $\beta$-actin were as follows: Sense, 5'-AGTTGCGTTACACCC TTTCTTGAC-3' and antisense, 5'-GCTCGCTCCAACCGA CTGC-3'.

Amplification of PDGFR- $\beta$ was performed for 40 cycles of $10 \mathrm{sec}$ at $95^{\circ} \mathrm{C}, 10 \mathrm{sec}$ at $58^{\circ} \mathrm{C}$ and $20 \mathrm{sec}$ at $72^{\circ} \mathrm{C}$. Amplification of $\beta$-actin was performed for 40 cycles of $15 \mathrm{sec}$ at $95^{\circ} \mathrm{C}$, $15 \mathrm{sec}$ at $60^{\circ} \mathrm{C}$ and $30 \mathrm{sec}$ at $72^{\circ} \mathrm{C}$. A $10-\mu 1$ aliquot of each amplified PCR product underwent electrophoresis in a $3 \%$ agarose gel containing ethidium bromide.

Immunohistochemical staining. Immunohistochemical studies of PDGFR- $\beta$ were performed on formalin-fixed, paraffin-embedded surgical specimens obtained from the gastric cancer patients. The section width was specified as $4 \mu \mathrm{m}$. The tissue sections were deparaffinized and soaked in $10 \mathrm{mM}$ sodium citrate buffer $(\mathrm{pH} 6.0)$ at $121^{\circ} \mathrm{C}$ for $15 \mathrm{~min}$ to retrieve cell antigens. Blocking was performed twice. First, endogenous peroxidase activity was blocked with $3 \%$ hydrogen peroxide solution for $5 \mathrm{~min}$. Next, protein activity was blocked with $5 \%$ skimmed milk for $5 \mathrm{~min}$. Subsequent to blocking, the sections were incubated overnight at $4^{\circ} \mathrm{C}$ to allow antigen-antibody reactions to occur. Peroxidase-labeled polymer (EnVision+, rabbit; Dako, Glostrup, Denmark) was used to detect signals of the antigen-antibody reactions. All sections were counterstained with hematoxylin. The primary rabbit polyclonal antibodies against PDGFR- $\beta$ (catalog no., HPA028499; Atlas Antibodies, Stockholm, Sweden) were used at a dilution of 1:100.

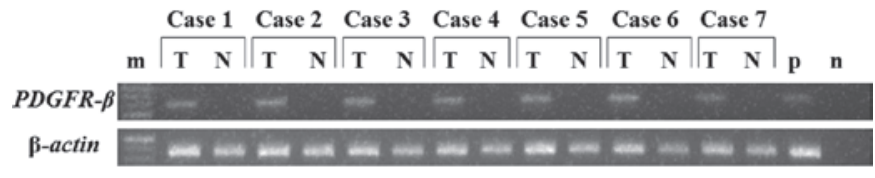

Figure 1. Reverse-transcription polymerase chain reaction. Expression of platelet-derived growth factor receptor- $\beta$ (PDGFR- $\beta$ ) mRNA was significantly higher in the cancer tissue $(\mathrm{T})$ than in the paired normal adjacent mucosa (N). m, (molecular) marker; p, positive control; $n$, negative control.

RT-quantitative (q)PCR. RT-qPCR was performed using iQ SYBR Green Supermix (Bio-Rad Laboratories, Inc.). PCR was performed in a total volume of $15 \mu 1$, which included $0.2 \mu \mathrm{g}$ cDNA, $0.4 \mu \mathrm{M}$ of each primer, $7.5 \mu \mathrm{l}$ iQ SYBR-Green Supermix containing dATP, dCTP, dGTP and dTTP at concentrations of $400 \mu \mathrm{M}$ each, and $50 \mathrm{U} / \mathrm{ml}$ of iTag DNA polymerase. The PCR cycling conditions consisted of $10 \mathrm{~min}$ at $95^{\circ} \mathrm{C}$, followed by 40 cycles of denaturation of the cDNA for $10 \mathrm{sec}$ at $95^{\circ} \mathrm{C}$, annealing for $10 \mathrm{sec}$ at $56^{\circ} \mathrm{C}\left(60^{\circ} \mathrm{C}\right.$ for $\beta$-actin $)$ and a primer extension for $20 \mathrm{sec}$ at $72^{\circ} \mathrm{C}$, followed by $10 \mathrm{~min}$ at $72^{\circ} \mathrm{C}$. To distinguish specific from non-specific products and primer dimers, melting curve analyses were performed. To evaluate specific mRNA expression in the samples, a standard curve was created for each run, based on three points from human control cDNA (Clontech Laboratories, Inc., CA, USA). The concentrations of each sample were calculated by relating their crossing point to the standard curve. The number of experimental repeats was three times, and the method used for quantitation was relative quantities (iQ5 software version 2.0; Bio-Rad Laboratories, Inc.).

Statistical analysis. Differences between gene expression levels in the gastric cancer and adjacent normal mucosa samples were compared using the Wilcoxon test. The associations between gene expression and potential explanatory variables, including age, gender, tumor size, histological type, serosal invasion, lymph node metastasis, tumor-node-metastasis (TNM) stage (12), lymphatic invasion and venous invasion, were evaluated using the $\chi^{2}$ test. Associations between PDGFR- $\beta$ gene expression and survival were assessed using the Kaplan-Meier method and were compared by the log-rank test. A Cox proportional-hazards model was used to perform univariate analyses and stepwise multivariate analyses to determine risk factors. All statistical analyses were performed with the Dr. SPSS II program, version 11.0.1 J for Windows (SPSS, Inc., Chicago, IL, USA). Two-sided P-values were calculated, and a difference was considered statistically significant at $\mathrm{P}<0.05$. Data are expressed as median (range).

\section{Results}

PDGFR- $\beta$ mRNA expression in specimens of cancer tissue and adjacent normal mucosa. PDGFR- $\beta$ gene expression was examined by RT-PCR, using gastric cancer tissue and normal gastric mucosal tissue obtained from 7 patients (Fig. 1). The results revealed that $P D G F R-\beta$ expression was significantly higher in tumor tissue than in normal gastric mucosal tissue. Therefore, $P D G F R-\beta$ gene expression was examined by RT-qPCR in gastric cancer tissue and normal gastric mucosa 
Table I. Association between PDGFR- $\beta$ mRNA expression and clinicopathological features.

\begin{tabular}{|c|c|c|c|}
\hline Variable & Low PDGFR- $\beta$ expression $(\mathrm{n}=67)$ & High $P D G F R-\beta$ expression $(\mathrm{n}=67)$ & P-value \\
\hline \multicolumn{4}{|l|}{ Age, years } \\
\hline$<65$ & 26 & 30 & \multirow[t]{2}{*}{0.484} \\
\hline$\geq 65$ & 41 & 37 & \\
\hline \multicolumn{4}{|l|}{ Gender } \\
\hline Male & 45 & 47 & \multirow[t]{2}{*}{0.710} \\
\hline Female & 22 & 20 & \\
\hline \multicolumn{4}{|l|}{ Tumor size, $\mathrm{cm}$} \\
\hline$<6$ & 27 & 33 & \multirow[t]{2}{*}{0.297} \\
\hline$\geq 6$ & 40 & 34 & \\
\hline \multicolumn{4}{|l|}{ Histological type } \\
\hline Differentiated & 24 & 29 & \multirow[t]{2}{*}{0.377} \\
\hline Undifferentiated & 43 & 38 & \\
\hline \multicolumn{4}{|l|}{ Serosal invasion } \\
\hline Absent & 27 & 26 & \multirow[t]{2}{*}{0.860} \\
\hline Present & 40 & 41 & \\
\hline \multicolumn{4}{|c|}{ Lymph node metastasis } \\
\hline Absent & 8 & 8 & \multirow[t]{2}{*}{1.000} \\
\hline Present & 59 & 59 & \\
\hline \multicolumn{4}{|l|}{ TNM stage } \\
\hline II & 19 & 21 & \multirow[t]{2}{*}{0.706} \\
\hline III & 48 & 46 & \\
\hline \multicolumn{4}{|l|}{ Lymphatic invasion } \\
\hline Absent & 14 & 16 & \multirow[t]{2}{*}{0.679} \\
\hline Present & 53 & 51 & \\
\hline \multicolumn{4}{|l|}{ Venous invasion } \\
\hline Absent & 21 & 12 & \multirow[t]{2}{*}{0.071} \\
\hline Present & 46 & 55 & \\
\hline
\end{tabular}

PDGFR- $\beta$, platelet-derived growth factor receptor- $\beta$; TNM, tumor-node-metastasis.

in 75 patients for whom samples of both gastric cancer tissue and normal gastric mucosal tissue were available. The mRNA expression levels of $P D G F R-\beta$ in specimens of cancer tissue and adjacent normal mucosa obtained from 7 patients with gastric cancer were analyzed by RT-PCR (Fig. 1). PDGFR- $\beta$ mRNA expression was significantly higher in the cancer tissues than in the paired normal adjacent mucosa. PDGFR- $\beta$ mRNA expression was confirmed in clinical samples $(\mathrm{n}=75)$ by RT-qPCR. Expression levels of the PDGFR- $\beta$ gene were significantly higher in the cancer tissues compared with the adjacent normal mucosa ( $\mathrm{P}=0.009$; Fig. 2).

Immunohistochemistry of PDGFR- $\beta$ expression. Expression of $P D G F R-\beta$ protein was evaluated by immunohistochemical analysis of resected specimens of gastric cancer. Positive staining for $P D G F R-\beta$ was observed in the tumor stromal cells of the gastric cancer tissue in differentiated and undifferentiated types of gastric cancer (Fig. 3).

Associations between PDGFR- $\beta$ mRNA expression levels and clinicopathological features. Expression levels of the

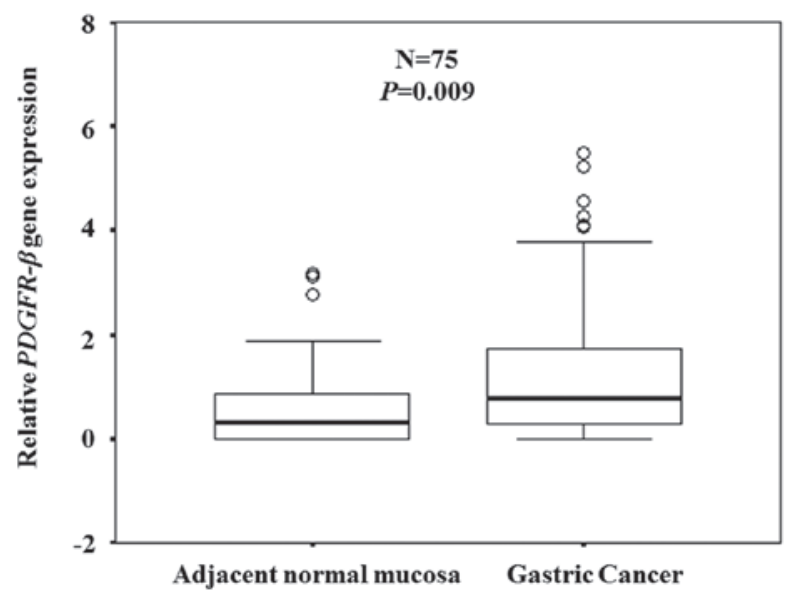

Figure 2. Comparison of platelet-derived growth factor receptor- $\beta$ (PDGFR- $\beta$ ) mRNA expression levels between gastric cancer tissue and adjacent normal mucosa. Box boundaries represent the 25 th and 75 th percentiles of the observed values, capped bars represent the 10th and 90th percentiles, and the solid line represents the median. P-values were calculated by the Wilcoxon signed-rank test. Expression levels of the PDGFR- $\beta$ gene were higher in the cancer tissues than in the adjacent normal mucosa $(\mathrm{P}=0.009)$. 
Table II. Univariate and multivariate Cox proportional hazards analysis of clinicopathological factors.

\begin{tabular}{|c|c|c|c|c|c|c|c|}
\hline \multirow[b]{2}{*}{ Variable } & \multirow[b]{2}{*}{$\mathrm{n}$} & \multicolumn{3}{|c|}{ Univariate } & \multicolumn{3}{|c|}{ Multivariate } \\
\hline & & Hazard ratio & $95 \% \mathrm{CI}$ & P-value & Hazard ratio & $95 \%$ CI & P-value \\
\hline \multicolumn{8}{|l|}{ Age, years } \\
\hline$<65$ & 56 & 1 & $0.356-1.319$ & 0.258 & & & \\
\hline$\geq 65$ & 78 & 0.685 & & & & & \\
\hline \multicolumn{8}{|l|}{ Gender } \\
\hline Male & 92 & 1 & $0.318-1.438$ & 0.310 & & & \\
\hline Female & 42 & 0.676 & & & & & \\
\hline \multicolumn{8}{|l|}{ Tumor size, cm } \\
\hline$<6$ & 60 & 1 & $0.553-2.060$ & 0.847 & & & \\
\hline$\geq 6$ & 74 & 1.067 & & & & & \\
\hline \multicolumn{8}{|l|}{ Histological type } \\
\hline Differentiated & 53 & 1 & $0.497-1.907$ & 0.937 & & & \\
\hline Undifferentiated & 81 & 0.973 & & & & & \\
\hline \multicolumn{8}{|l|}{ Serosal invasion } \\
\hline Absent & 53 & 1 & $0.753-3.118$ & 0.239 & & & \\
\hline Present & 81 & 1.532 & & & & & \\
\hline \multicolumn{8}{|c|}{ Lymph node metastasis } \\
\hline Absent & 16 & 1 & $0.655-11.356$ & 0.168 & & & \\
\hline Present & 118 & 2.726 & & & & & \\
\hline \multicolumn{8}{|l|}{ TNM stage } \\
\hline II & 40 & 1 & $1.039-6.019$ & $0.041^{\mathrm{a}}$ & 1 & $1.071-6.220$ & $0.035^{\mathrm{a}}$ \\
\hline III & 94 & 2.501 & & & 2.581 & & \\
\hline \multicolumn{8}{|c|}{ Lymphatic invasion } \\
\hline Absent & 30 & 1 & $0.456-2.201$ & 0.997 & & & \\
\hline Present & 104 & 1.002 & & & & & \\
\hline \multicolumn{8}{|l|}{ Venous invasion } \\
\hline Absent & 33 & 1 & $0.685-3.580$ & 0.288 & & & \\
\hline Present & 101 & 1.566 & & & & & \\
\hline \multicolumn{8}{|c|}{$P D G F R-\beta$ expression } \\
\hline Low & 67 & 1 & $1.002-3.887$ & $0.049^{\mathrm{a}}$ & 1 & $1.032-4.029$ & $0.040^{\mathrm{a}}$ \\
\hline High & 67 & 1.973 & & & 2.039 & & \\
\hline
\end{tabular}

${ }^{\text {aa }}<0.05$. PDGFR- $\beta$, platelet-derived growth factor receptor- $\beta$; TNM, tumor-node-metastasis.

A

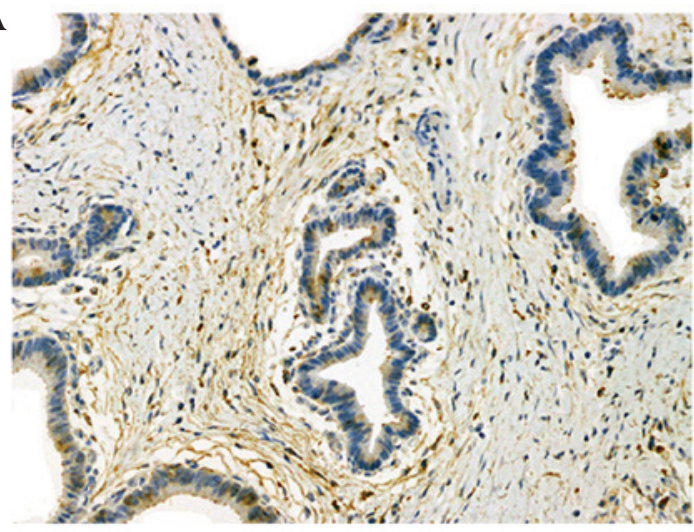

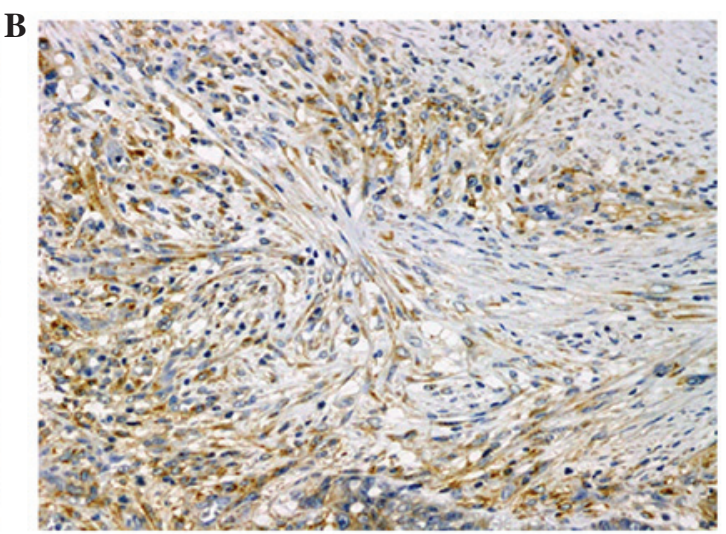

Figure 3. Immunohistochemical analysis of platelet-derived growth factor receptor- $\beta$ (PDGFR- $\beta$ ) expression. Expression of PDGFR- $\beta$ protein was evaluated by immunohistochemical analysis of resected specimens of gastric cancer. Positive staining for PDGFR- $\beta$ was observed in the tumor stromal cells of gastric cancer tissue in (A) differentiated and (B) undifferentiated types of gastric cancer. 


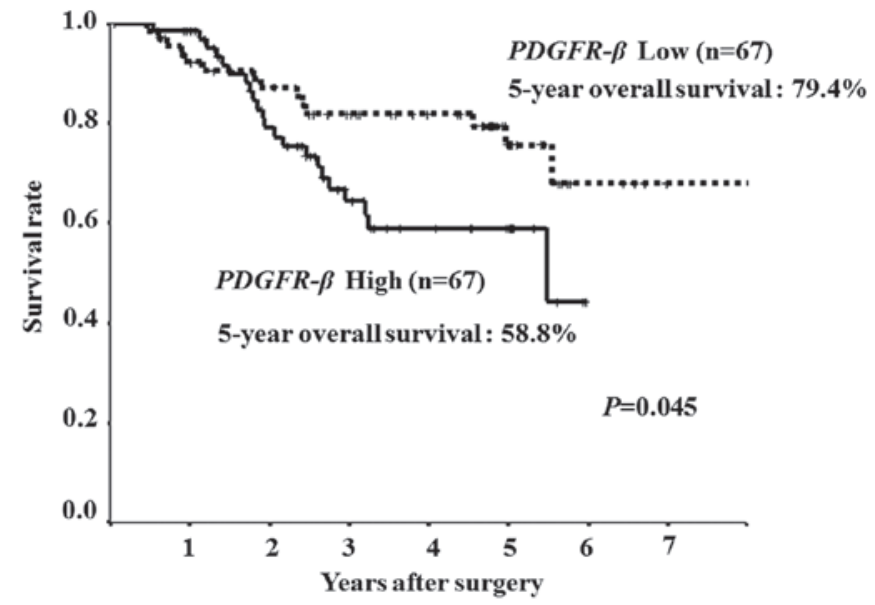

Figure 4. Association between platelet-derived growth factor receptor- $\beta$ $(P D G F R-\beta)$ mRNA expression and post-operative survival. Expression levels of the PDGFR- $\beta$ gene were categorized as low or high according to the median value. The post-operative survival rate was analyzed by the Kaplan-Meier method, and differences in survival rates were assessed by the log-rank test. Overall survival was significantly poorer in patients with high expression levels of the PDGFR- $\beta$ gene than in those with low expression levels $(\mathrm{P}=0.045)$

PDGFR- $\beta$ gene were categorized as low or high according to the median value. The associations between gene expression and clinicopathological features were then examined. Expression levels of the PDGFR- $\beta$ gene were not found to be associated with any clinicopathological variable (Table I).

Associations between PDGFR- $\beta$ mRNA expression levels and outcome. The expression levels of the PDGFR- $\beta$ gene were categorized as low or high according to the median expression value. Overall survival was significantly poorer in the patients with high expression levels (5-year overall survival rate, 58.8\%) of the PDGFR- $\beta$ gene than in those with low expression levels (5-year overall survival rate, $79.4 \%)(\mathrm{P}=0.045$; Fig. 4).

Univariate and multivariate analyses of the associations between clinicopathological factors and PDGFR- $\beta$ mRNA expression levels with regard to outcome. The following variables were included in univariate analysis: Age, gender, tumor size, histological grade, serosal invasion, lymph-node metastasis, TNM stage, lymphatic invasion, venous invasion and PDGFR- $\beta$ gene expression. Only TNM stage and $P D G F R-\beta$ gene expression were significantly associated with the outcome. Upon multivariate Cox proportional-hazards regression analysis, TNM stage $(\mathrm{P}=0.035)$ and high $P D G F R-\beta$ gene expression $(\mathrm{P}=0.040)$ was independently and inversely associated with outcome (Table II).

\section{Discussion}

The standard treatment for stage II/III gastric cancer is a curative resection and adjuvant chemotherapy. The overall survival rate of patients with stage II/III gastric cancer remains unsatisfactory, even after curative surgery and adjuvant chemotherapy with S-1 (2-4). Improved risk stratification and personalized medicine based on biomarker analysis will hopefully improve outcomes in stage II/III gastric cancer. The present study therefore focused on $P D G F R-\beta$ and examined the clinical significance of $P D G F R-\beta$ expression in patients with stage II/III gastric cancer who received curative surgery and post-operative adjuvant chemotherapy with S-1.

The present study examined the expression levels of $P D G F R-\beta$ mRNA in gastric cancer and adjacent normal mucosa. Studies have previously compared the relative mRNA expression levels of the PDGFR- $\beta$ gene between various types of cancer tissue and adjacent normal mucosa. Erben et al reported that $P D G F R-\beta$ mRNA expression is higher in rectal cancer tissue than in normal rectal mucosa (13). Antoniades et al found that PDGF and PDGFR- $\beta$ mRNA are strongly expressed in lung carcinoma tissue, but not in normal lung tissue (14). Vrekoussis et al showed that immunohistochemical expression levels of endothelial PDGFR- $\beta$ are significantly higher in breast cancer tissue than in normal breast tissue (15), and Guo et al reported that the positive rate of immunohistochemical PDGFR- $\beta$ expression is significantly higher in gastric carcinoma tissue than in normal gastric mucosa tissue (16). The present results are consistent with these findings. PDGFR- $\beta$ mRNA expression levels were significantly higher in 75 specimens of gastric cancer tissue than in the paired adjacent normal mucosa.

The associations between PDGFR- $\beta$ mRNA expression levels and clinicopathological features in gastric cancer were then evaluated. Kodama et al reported that PDGFR- $\beta$ expression correlates with lymph node metastasis in gastric cancer (5). Suzuki et al showed that activation of PDGFR- $\beta$ correlates with the depth of tumor invasion in gastric cancer (17), and Guo et al reported that PDGFR- $\beta$ expression positively correlates with the depth of tumor invasion, lymph node metastasis and TNM stage in gastric cancer (16). By contrast, the expression levels of PDGFR- $\beta$ mRNA were not associated with any clinicopathological features in the present study.

Finally, the present study assessed the associations between PDGFR- $\beta$ gene expression levels and outcome in stage II/III gastric cancer after curative resection and adjuvant chemotherapy with $\mathrm{S}-1$. Paulsson et al reported that high stromal PDGFR- $\beta$ expression significantly correlates with shorter recurrence-free and cancer-specific survival times in various types of breast cancer (18), while Hägglöf et al showed that stromal PDGFR- $\beta$ expression predicts cancer-specific survival in various types of prostate cancer (19). Sato et al (20) reported that PDGFR- $\beta$ expression is a significant prognostic factor in grade II/III astrocytoma and grade IV glioblastoma. Chen et al (21) found that PDGFR- $\beta$ overexpression alone is not a significant predictor of either disease-free survival or overall survival, whereas $P D G F R-\alpha / P D G F R-\beta /$ vascular endothelial growth factor coexpression significantly correlates with poorer disease-free survival and overall survival in patients with stage I-IV hepatocellular carcinoma. By contrast, Shinohara et al reported that the levels of $P D G F R-\beta$ expression are not a statistically significant predictor of 5-year overall survival in either limited or extensive small-cell lung cancer (22). The present results showed that high $P D G F R-\beta$ expression levels were a significant independent predictor of a poorer 5-year overall survival rate in patients with stage II/III gastric cancer after curative resection and post-operative adjuvant chemotherapy with S-1. Upon multivariate Cox proportional hazards 
regression analysis, high levels of $P D G F R-\beta$ gene expression were independently and inversely associated with outcome.

The molecular mechanisms and functional impact of $P D G F R-\beta$ expression in cancer remain to be fully elucidated. PDGFR- $\beta$ promotes the proliferation of tumor-associated fibroblasts and neovascular endothelial cells participating in tumor angiogenesis; it also increases IFP, and a higher IFP is associated with greater $P D G F R-\beta$ expression. Tailor et al reported that the IFP was higher in the high PDGFR- $\beta$ group in nude mice bearing human non-small-cell lung cancer A549 xenografts (23). Increased IFP acts as a barrier to drug distribution and the migration of cytotoxic $\mathrm{T}$ lymphocytes that target tumor cells (24). High IFP is thus a prognostic factor of tumors. Yeo et al reported that IFP is a prognostic factor in patients with cervical cancer (25). Milosevic et al (26) also showed that IFP is a predictor of survival in patients with cervical cancer. These findings suggest that reducing the IFP may contribute to improved survival. Pietras et al (27) demonstrated that the inhibition of PDGFR reduces the IFP and increases the capillary-to-interstitium transport of ${ }^{51} \mathrm{Cr}$-EDTA in PROb rat colonic carcinomas. Pietras et al (28) also reported that the inhibition of PDGFR signaling enhances the antitumor effect of chemotherapy on subcutaneous KAT-4 tumors in FOX Chase severe combined immune deficiency mice. Emerich et al (29) showed that infusion of the bradykinin agonist Cereport (labradimil or RMP-7) in rats bearing experimental tumors reduces the IFP and increases deposition of $\left[{ }^{14} \mathrm{C}\right]$-carboplatin in tumor tissue. These findings suggest that high PDGFR- $\beta$ expression is associated with high IFP and causes resistance to chemotherapy by reducing blood flow to tumors and decreasing drug delivery in patients with gastric cancer after curative surgery and post-operative adjuvant chemotherapy with S-1. Imatinib is a PDGFR inhibitor. Wiig et al (30) reported that rats with colonic carcinomas treated with imatinib exhibited reduced IFP. Kim et al (24) demonstrated that treatment with imatinib markedly enhances the chemotherapeutic effects of antitumor drugs such as 5-fluorouracil and paclitaxel in vivo in gastric carcinoma MKN-45 cells transplanted into nude mice. These findings indirectly suggest that PDGFR- $\beta$ expression may antagonize the antitumor effects of chemotherapy. However, further investigations are necessary to elucidate the underlying mechanisms.

In conclusion, PDGFR- $\beta$ gene expression levels were higher in gastric cancer tissue than in adjacent normal mucosa in the present study, and the high expression of this gene was significantly associated with a poor outcome in patients with stage II/III gastric cancer who underwent curative resection and received adjuvant chemotherapy with $\mathrm{S}-1$. These findings suggest that PDGFR- $\beta$ overexpression is a useful, independent predictor of outcome in patients with stage II/III gastric cancer who receive curative surgery and post-operative adjuvant chemotherapy with S-1.

\section{Acknowledgements}

The authors would like to thank Medical Network K.K for preparing the original manuscript. The study was supported by the Yokohama Foundation for Advanced Medical Science (grant no. 18-7A-4).

\section{References}

1. Jemal A, Bray F, Center MM, Ferlay J, Ward E and Forman D: Global cancer statistics. CA Cancer J Clin 61: 69-90, 2011.

2. Sakuramoto S, Sasako M, Yamaguchi T, Kinoshita T, Fujii M, Nashimoto A, Furukawa H, Nakajima T, Ohashi Y, Imamura H, et al: Adjuvant chemotherapy for gastric cancer with S-1, an oral fluoropyrimidine. N Engl J Med 357: 1810-1820, 2007.

3. Sano T, Sasako M, Yamamoto S, Nashimoto A, Kurita A, Hiratsuka M, Tsujinaka T, Kinoshita T, Arai K, Yamamura Y and Okajima K: Gastric cancer surgery: Morbidity and mortality results from a prospective randomized controlled trial comparing D2 and extended para-aortic lymphadenectomy-Japan Clinical Oncology Group study 9501. J Clin Oncol 22: 2767-2773, 2004.

4. Sasako M, Sakuramoto S, Katai H, Kinoshita T, Furukawa H, Yamaguchi T, Nashimoto A, Fujii M, Nakajima T and Ohashi Y: Five-year outcomes of a randomized phase III trial comparing adjuvant chemotherapy with S-1 versus surgery alone in stage II or III gastric cancer. J Clin Oncol 29: 4387-4393, 2011.

5. Kodama M, Kitadai Y, Sumida T, Ohnishi M, Ohara E, Tanaka M, Shinagawa K, Tanaka S, Yasui W and Chayama K: Expression of platelet-derived growth factor (PDGF)-B and PDGF-receptor $\beta$ is associated with lymphatic metastasis in human gastric carcinoma. Cancer Sci 101: 1984-1989, 2010.

6. Sumida T, Kitadai Y, Shinagawa K, Tanaka M, Kodama M, Ohnishi M, Ohara E, Tanaka S, Yasui W and Chayama K: Anti-stromal therapy with imatinib inhibits growth and metastasis of gastric carcinoma in an orthotopic nude mouse model. Int J Cancer 128: 2050-2062, 2011.

7. Tsuda T, Yoshida K, Tsujino T, Nakayama H, Kajiyama G and Tahara E: Coexpression of platelet-derived growth factor (PDGF) A-chain and PDGF receptor genes in human gastric carcinomas. Jpn J Cancer Res 80: 813-817, 1989.

8. Ostman A: PDGF receptors-mediators of autocrine tumor growth and regulators of tumor vasculature and stroma. Cytokine Growth Factor Rev 15: 275-286, 2004.

9. Risau W, Drexler H, Mironov V, Smits A, Siegbahn A, Funa K and Heldin $\mathrm{CH}$ : Platelet-derived growth factor is angiogenic in vivo. Growth Factors 7: 261-266, 1992.

10. Bergers G, Song S, Meyer-Morse N, Bergsland E and Hanahan D: Benefits of targeting both pericytes and endothelial cells in the tumor vasculature with kinase inhibitors. J Clin Invest 111: 1287-1295, 2003.

11. Pietras K: Increasing tumor uptake of anticancer drugs with imatinib. Semin Oncol 31 (2 Suppl 6): S18-S23, 2004.

12. Sobin LH, Gospodarowicz MK and Wittekind C (eds): International Union Against Cancer (UICC) TNM Classification of Malignant Tumors. 7th edition. Wiley-Blackwell, Oxford, pp73-77, 2009.

13. Erben P, Horisberger K, Muessle B, Müller MC, Treschl A, Ernst T, Kähler G, Ströbel P, Wenz F, Kienle P, et al: mRNA expression of platelet-derived growth factor receptor-beta and C-KIT: Correlation with pathologic response to cetuximab-based chemoradiotherapy in patients with rectal cancer. Int J Radiat Oncol Biol Phys 72: 1544-1550, 2008.

14. Antoniades HN, Galanopoulos T, Neville-Golden J and O'Hara CJ: Malignant epithelial cells in primary human lung carcinomas coexpress in vivo platelet-derived growth factor (PDGF) and PDGF receptor mRNAs and their protein products. Proc Natl Acad Sci USA 89: 3942-3946, 1992.

15. Vrekoussis T, Stathopoulos EN, Kafousi M, Navrozoglou I and Zoras O: Expression of endothelial PDGF receptors alpha and beta in breast cancer: Up-regulation of endothelial PDGF receptor beta. Oncol Rep 17: 1115-1119, 2007.

16. Guo Y, Yin J, Zha L and Wang Z: Clinicopathological significance of platelet-derived growth factor B, platelet-derived growth factor receptor- $\beta$, and E-cadherin expression in gastric carcinoma. Contemp Oncol (Pozn) 17: 150-155, 2013.

17. Suzuki S, Dobashi Y,Hatakeyama Y, Tajiri R, Fujimura T,Heldin $\mathrm{CH}$ and Ooi A: Clinicopathological significance of platelet-derived growth factor (PDGF)-B and vascular endothelial growth factor-A expression, PDGF receptor- $\beta$ phosphorylation, and microvessel density in gastric cancer. BMC cancer 10: 659, 2010.

18. Paulsson J, Sjöblom T, Micke P, Pontén F, Landberg G, Heldin CH, Bergh J, Brennan DJ, Jirström K and Ostman A: Prognostic significance of stromal platelet-derived growth factor beta-receptor expression in human breast cancer. Am J Pathol 175: 334-341, 2009. 
19. Hägglöf C, Hammarsten P, Josefsson A, Stattin P, Paulsson J, Bergh A and Ostman A: Stromal PDGFRbeta expression in prostate tumors and non-malignant prostate tissue predicts prostate cancer survival. PloS One 5: e10747, 2010.

20. Sato S, Sato Y, Hatakeyama K, Marutsuka K, Yamashita A, Takeshima $\mathrm{H}$ and Asada Y: Quantitative analysis of vessels with smooth muscle layer in astrocytic tumors: correlation with histological grade and prognostic significance. Histol Histopathol 26 497-504, 2011

21. Chen L, Shi Y, Jiang CY, Wei LX, Lv YL, Wang YL and Dai GH: Coexpression of PDGFR-alpha, PDGFR-beta and VEGF as a prognostic factor in patients with hepatocellular carcinoma. Int J Biol Markers 26: 108-116, 2011.

22. Shinohara ET, Gonzalez A, Massion PP, Olson SJ, Albert JM, Shyr Y, Carbone DP, Johnson DH, Hallahan DE and Lu B PDGFR-beta expression in small cell lung cancer patients. Int J Radiat Oncol Biol Phys 67: 431-437, 2007.

23. Tailor TD, Hanna G, Yarmolenko PS, Dreher MR, Betof AS, Nixon AB, Spasojevic I and Dewhirst MW: Effect of pazopanib on tumor microenvironment and liposome delivery. Mol Cancer Ther 9: 1798-1808, 2010.

24. Kim R, Emi M, Arihiro K, Tanabe K, Uchida Y and Toge T: Chemosensitization by STI571 targeting the platelet-derived growth factor/platelet-derived growth factor receptor-signaling pathway in the tumor progression and angiogenesis of gastric carcinoma. Cancer 103: 1800-1809, 2005.
25. Yeo SG, Kim JS, Cho MJ, Kim KH and Kim JS: Interstitial fluid pressure as a prognostic factor in cervical cancer following radiation therapy. Clin Cancer Res 15: 6201-6207, 2009.

26. Milosevic M, Fyles A, Hedley D, Pintilie M, Levin W, Manchul L and Hill R: Interstitial fluid pressure predicts survival in patients with cervix cancer independent of clinical prognostic factors and tumor oxygen measurements. Cancer Res 61: 6400-6405, 2001.

27. Pietras K, Ostman A, Sjöquist M, Buchdunger E, Reed RK, Heldin $\mathrm{CH}$ and Rubin K: Inhibition of platelet-derived growth factor receptors reduces interstitial hypertension and increases transcapillary transport in tumors. Cancer Res 61: 2929-2934, 2001.

28. Pietras K, Rubin K, Sjöblom T, Buchdunger E, Sjöquist M, Heldin $\mathrm{CH}$ and Ostman A: Inhibition of PDGF receptor signaling in tumor stroma enhances antitumor effect of chemotherapy. Cancer Res 62: 5476-5484, 2002.

29. Emerich DF, Dean RL, Snodgrass P, Lafreniere D, Agostino M, Wiens T, Xiong H, Hasler B, Marsh J, Pink M, et al: Bradykinin modulation of tumor vasculature: II. activation of nitric oxide and phospholipase A2/prostaglandin signaling pathways synergistically modifies vascular physiology and morphology to enhance delivery of chemotherapeutic agents to tumors. J Pharmacol Exp Ther 296: 632-641, 2001.

30. Wiig H, Tveit E, Hultborn R, Reed RK and Weiss L: Interstitial fluid pressure in DMBA-induced rat mammary tumours. Scand J Clin Lab Invest 42: 159-164, 1982. 